\title{
Systematic review of invasive meningococcal disease epidemiology in the Eastern Mediterranean and North Africa region
}

\author{
Alp Giray Dogu', Anouk M. Oordt-Speets², Femke van Kessel-de Bruijn², Mehmet Ceyhan ${ }^{3}$ and
} Amine Amiche ${ }^{1 *}$

\begin{abstract}
Background: Invasive meningococcal disease (IMD) represents a global health burden. However, its epidemiology in the Eastern Mediterranean (EM) and North Africa (NA) regions is currently not well understood. This review had four key objectives: to describe asymptomatic meningococcal carriage, IMD epidemiology (e.g. serogroup prevalence, case-fatality rates [CFRs]), IMD presentation and management (e.g. clinical diagnosis, antibiotic treatments) and economic impact and evaluation (including health technology assessment [HTA] recommendations) in EM and NA.

Methods: A systematic literature search (MEDLINE and EMBASE) was conducted (January 2000 to February 2021). Search strings included meningococcal disease and the regions/countries of interest. Identified publications were screened sequentially by title/abstract, followed by screening of the full-text article; articles were also assessed on methodological quality. Literature reviews, genetic sequencing or diagnostic accuracy studies, or other non-pertinent publication type were excluded. An additional grey literature search (non-peer-reviewed sources; start date January 2000) was conducted to the end of April 2019.

Results: Of the 1745 publications identified, 79 were eligible for the final analysis ( $n=61$ for EM and $n=19$ for NA; one study was relevant to both). Asymptomatic meningococcal carriage rates were 0-33\% in risk groups (e.g. military personnel, pilgrims) in EM (no data in NA). In terms of epidemiology, serogroups A, B and W were most prevalent in EM compared with serogroups B and C in NA. IMD incidence was 0-20.5/100,000 in EM and 0.1-3.75/100,000 in NA (reported by $7 / 15$ countries in EM and $3 / 5$ countries in NA). CFRs were heterogenous across the EM, ranging from 0 to $57.9 \%$, but were generally lower than 50\%. Limited NA data showed a CFR of 0-50\%. Data were also limited in terms of IMD presentation and management, particularly relating to clinical diagnosis/antibiotic treatment. No economic evaluation or HTA studies were found.
\end{abstract}

Conclusions: High-risk groups remain a significant reservoir of asymptomatic meningococcal carriage. It is probable that inadequacies in national surveillance systems have contributed to the gaps identified. There is consequently a pressing need to improve national surveillance systems in order to estimate the true burden of IMD and guide appropriate prevention and control programmes in these regions.

Keywords: Invasive meningococcal disease, Epidemiology, Disease burden, EMNA region, Eastern Mediterranean, North Africa, Systematic review

\footnotetext{
*Correspondence: amine.amiche@sanofi.com

1 Sanofi Pasteur, Dubai, UAE

Full list of author information is available at the end of the article
} permitted by statutory regulation or exceeds the permitted use, you will need to obtain permission directly from the copyright holder. To view a copy of this licence, visit http://creativecommons.org/licenses/by/4.0/. The Creative Commons Public Domain Dedication waiver (http://creativecommons.org/publicdomain/zero/1.0/) applies to the data made available in this article, unless otherwise stated in a credit line to the data. 


\section{Background}

Neisseria meningitidis, a bacterium found exclusively in humans, poses a global health risk [1]. Infection with $N$. meningitidis usually results in asymptomatic carriage, in which the bacteria colonise the naso-oropharyngeal mucosa [2-4]. Globally, carriage prevalence varies both by region and age group $[2,5]$. International estimates indicate that carriage prevalence ranges from $4.5 \%$ in infants to $7.7 \%$ in children aged 10 years, peaking at $23.7 \%$ in adolescents (19 years) and decreasing to $7.8 \%$ by the age of 50 years $[2,5]$. It should be noted, however, that individual regions may have different carriage agedistributions [5, 6]. Although the majority of $N$. meningitidis carriages are cleared spontaneously (i.e. without treatment), in some cases the pathogen may pass through the naso-oropharyngeal mucosa, entering the bloodstream. Persistence of $N$. meningitidis in the bloodstream may subsequently result in invasive meningococcal disease (IMD) $[2,4]$.

IMD is the most severe type of meningococcal infection, with common clinical manifestations including meningitis and meningococcaemia [1]. Approximately 1.2 million IMD cases occur annually worldwide, and it is associated with a case-fatality rate (CFR) of approximately $10 \%[1,7]$. However, the CFR may increase significantly in cases of inadequate or delayed diagnosis and treatment, and varies according to serogroup [8,9]. Atypical clinical presentation has been observed for various serogroups (e.g. acute gastrointestinal symptoms for serogroup W, primary pneumonia for serogroup Y, septic arthritis for serogroups $C$ and $W$ ); such cases may be misdiagnosed, potentially leading to a high CFR $[1,8-$ 10]. The incidence of IMD, which may occur as sporadic, endemic or epidemic infection, is influenced by various factors. These include microbial factors (e.g. virulence), host susceptibility factors (e.g. age, medical conditions) and environmental factors such as geographical location (including travel to endemic/epidemic areas), seasonal variations, and mass gatherings [1, 7, 11-14]. Globally, the incidence of IMD is highest in infants and young children, with over $75 \%$ of all cases of meningococcal meningitis and meningococcaemia occurring in children aged $<5$ years. However, a second, smaller peak of incidence has been observed in adolescents and young adults [1, 15]. In addition, the CFR is age dependant, and is highest in older adults (aged $\geq 65$ years) $[16,17]$.

The majority of cases of IMD are caused by serogroups $\mathrm{A}, \mathrm{B}, \mathrm{C}, \mathrm{W}$ and $\mathrm{Y}[1,7,11]$. Given the unpredictability of IMD, proactive vaccination strategies are considered the best method to ensure population-wide protection [18]. Currently available vaccines provide coverage for serogroups A, B, C, W and Y; quadrivalent vaccines cover the serogroups $\mathrm{A}, \mathrm{C}, \mathrm{W}$ and $\mathrm{Y}$, while mono-/bivalent vaccines are available for prevention of disease caused by serogroups A, B and C [18]. Two pentavalent vaccines (ABCWY and ACYWX) are also currently in development $[19,20]$.

IMD is often associated with situations in which a high degree of crowding occurs, which includes events such as the Umrah and Hajj, which are mass gatherings of Muslim pilgrims in Saudi Arabia [11, 14, 21]. Attendance at the Hajj in particular may exceed 1 million non-resident attendees [22]. These gatherings have previously been associated with local and international outbreaks of IMD, as many pilgrims who attend Umrah/Hajj travel to Saudi Arabia from the African meningitis belt [13]. The latter is a geographical region stretching from Senegal to Ethiopia that has the highest burden of IMD in the world $[6,23]$. It is thought that this mass movement of pilgrims may influence the epidemiology of IMD in the Eastern Mediterranean (EM) and North Africa (NA) regions (referred to collectively as the EMNA region), allowing different serogroups to spread between regions and potentially resulting in local outbreaks of disease [24]. Despite these concerns, however, data on IMD are sparse or lacking in the EMNA region as a whole. Various surveillance systems (ranging from developed to suboptimal) are present in the African meningitis belt, Algeria, Morocco and Turkey, but few other countries in the region have established this type of infrastructure [25].

The aim of this systematic review is to describe asymptomatic meningococcal carriage, IMD epidemiology, IMD presentation and management, and economic impact and evaluation in the EMNA region.

\section{Methods \\ Objectives}

The key objectives of this study were to review the following in the EMNA region: (1) asymptomatic meningococcal carriage; (2) IMD epidemiology (serogroup distribution, incidence, CFRs and complications and sequelae); (3) IMD presentation and management (clinical presentation, hospitalisation, antibiotic treatment and prophylaxis/vaccination); (4) and economic impact and evaluation (including health technology assessment [HTA] recommendations).

\section{Systematic literature search}

A systematic review of the literature was performed following the Cochrane Collaboration and Preferred Reporting Items for Systematic Reviews and Meta-Analyses (PRISMA) guidelines [26]. A literature search of the MEDLINE and EMBASE databases was completed with date limits of 1 January 2000 to February 2021. The search strings included English-language terms for meningococcal disease, and the regions and countries of interest. 
Full details of the PRISMA checklist and the systematic review search strategy (including formulation of review questions, literature searches, selection procedure, data extraction and quality control) are included in Additional file 1 . Unless otherwise specified, dates and date ranges stated in the Results section indicate the time period during which the data contained in individual publications were collected, and not the year of publication.

The original search was conducted in the Asia, Middle East and Eurasia (AMEE) region. Given the importance of meningitis in the EMNA region, we have chosen to focus solely on studies relevant to that region in this manuscript. As mass gatherings of Muslim pilgrims are a regular occurrence in the EMNA region, Eurasian countries proximal to the Middle East with a majority Muslim population (i.e. Pakistan, Turkey) were also included in the EM region. For the purposes of this review, the EMNA region was divided into two sections (EM and NA). The EM region was defined as Bahrain, Iran, Iraq, Jordan, Kuwait, Lebanon, Oman, Pakistan, Palestinian Territories, Qatar, Saudi Arabia, Syria, Turkey, United Arab Emirates, and Yemen. The NA region was defined as Algeria, Egypt, Libya, Morocco, and Tunisia.

\section{Study screening}

Details of the search strategy can be found in Additional file 1 . Selection was not limited by language of the publication. Publications identified by the search were screened sequentially by title and abstract, followed by screening of the full-text article. Literature reviews, genetic sequencing or diagnostic accuracy studies, or other non-pertinent publication type were excluded. As most studies were not of a classical design suited to appraisal using existing standardised checklists, such as surveillance studies or cross-sectional studies, no checklists were used to assess the quality of the articles or to calculate a total quality score. Nevertheless, articles were assessed on their methodological quality without standardised checklists and one article was excluded because of major limitations in their design. To fill the gaps from the peer-reviewed literature, a grey literature search (i.e. hand search) was conducted in April 2019. Key websites (listed in Additional file 1) were searched using English search terms for relevant grey literature documents, conference abstracts and other data sources (including other websites) dating from January 2000 to April 2019.

\section{Data extraction}

Data on the key objectives were extracted and stratified by age group (children only [defined per study; variable age range], adults only, and children and adults), serogroup and population (general population, military, students, pilgrims, and household contacts of individuals with IMD) using a standard Excel spreadsheet. No formal assessment of publication bias was performed.

\section{Results}

The literature search identified a total of 1745 publications, of which 563 were duplicates (Fig. 1).

A total of 955 publications were excluded as they did not include data relevant to the objectives of this study, leaving 227 articles for full-text screening. An additional 48 articles were identified by hand search, and 16 articles were excluded as they were not found in full text. Following full-text screening of the remaining 259 articles, 164 articles were excluded as they did not meet the inclusion criteria (further details can be found in Fig. 1). A total of 95 articles were then considered for inclusion (i.e. included in qualitative synthesis) in the systematic literature review. Of these, 79 were relevant to the EM and NA regions; $(n=61$ and $n=19$ respectively, with one study spanning both regions).

Data were unavailable for objective 4 (economic impact and evaluation). Data for objectives 1-3 (asymptomatic meningococcal carriage, IMD epidemiology and IMD presentation and management, respectively) were not always available for all countries, and overall, there were fewer relevant publications identified in the NA versus the EM region (Additional file 1: Fig. S1).

\section{Objective 1: asymptomatic meningococcal carriage}

Here, we report the asymptomatic meningococcal carriage by age group (children, adults, and adults or children) in the general population or by risk group (household contact, military, pilgrim or student) in the EMNA region. Data were only available in the EM region (Table 1).

Data on asymptomatic meningococcal carriage in the general population were available for Turkey only $(n=6$ studies), spanning a time period of 2000-2018 [27-32]. As data were only available for one country, no overall conclusions can be drawn for the EM region as a whole. Asymptomatic carriage rates were 1.2 [27]-11.0\% [31] in children ( $\mathrm{n}=4$ studies), 1.3 [32]-10.3\% [31] in adults ( $\mathrm{n}=3$ studies) and 0.6 [29]-6.3\% [31] in a mixed group of children/adults ( $\mathrm{n}=2$ studies). Age ranges for childrenonly groups varied by study $(0-10$ years [27], 7-14 years [28], 0-14 years [30] and 10-17 years) [31].

For the risk groups (e.g. household contacts, military personnel, pilgrims or students), the most extensive data were available in the pilgrim population (Table 1). Data were available from Iran $(n=6)$ [33-38], Kuwait $(n=1)$ [39], Saudi Arabia $(n=6)$ [40-45], and Turkey $(n=3)$ [46-48]. Asymptomatic carriage rates ranged from $4.2 \%$ (Turkey) [46] to $32.9 \%$ (Iran) [35] in the military risk group ( $\mathrm{n}=3$ studies), from $0.0 \%$ (Iran [36], 


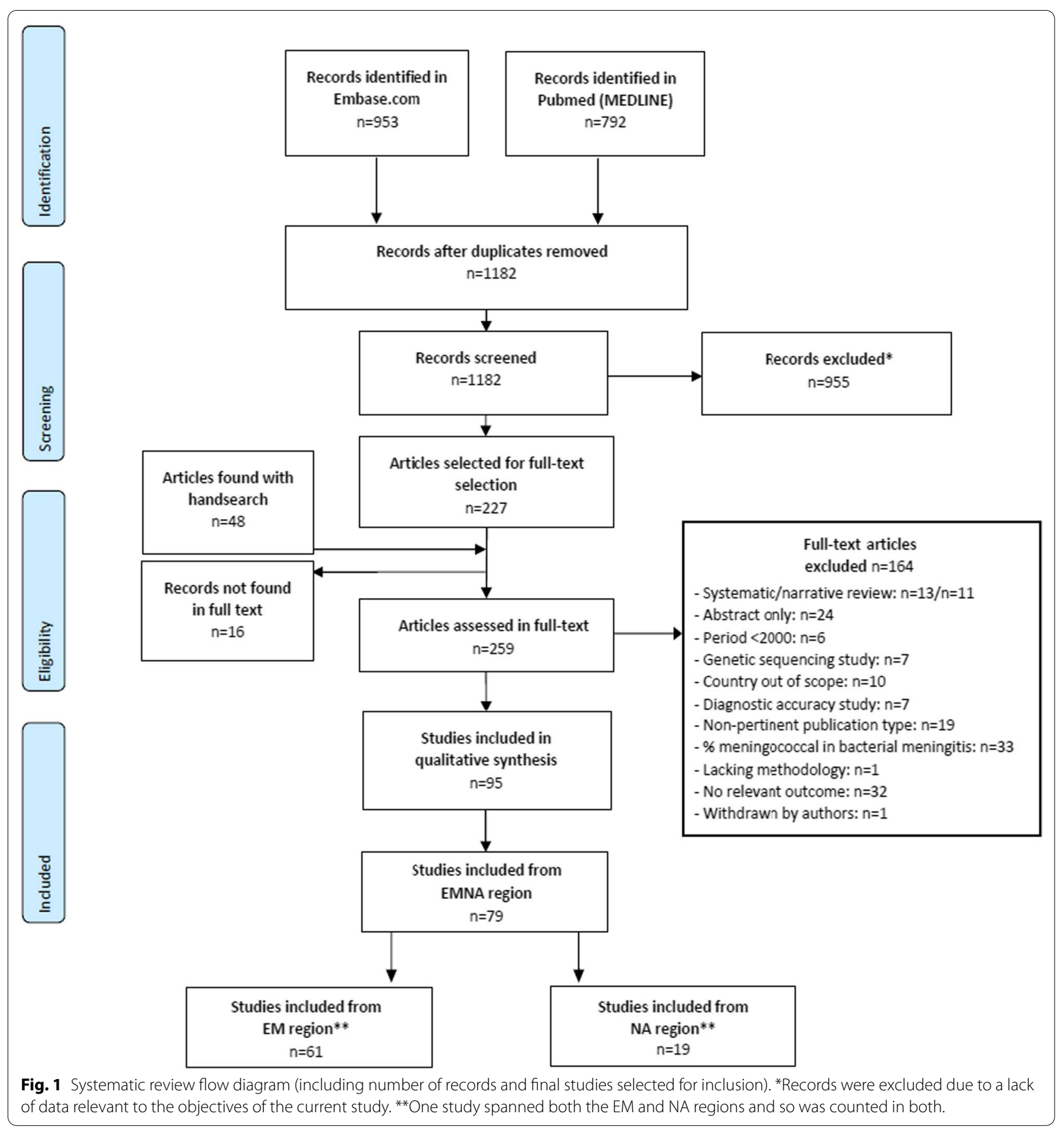

Kuwait [39]) to 27.4\% (Turkey [47]) in the pilgrim risk group ( $\mathrm{n}=11$ studies) and from 6.9 to $12.3 \%$ (both Iran $[37,38])$ in the student risk group ( $\mathrm{n}=2$ studies). One data point was available for household contacts, showing asymptomatic carriage at $25.6 \%$ (Turkey) [47].

\section{Objective 2: IMD epidemiology}

\section{Incidence}

In the EM region, IMD incidence data were identified for Bahrain $(n=1)$ [49], Iran $(n=1)$ [50], Kuwait $(n=1)$ [51], Qatar $(\mathrm{n}=1)$ [52], Saudi Arabia $(\mathrm{n}=4)$ [53-56], 


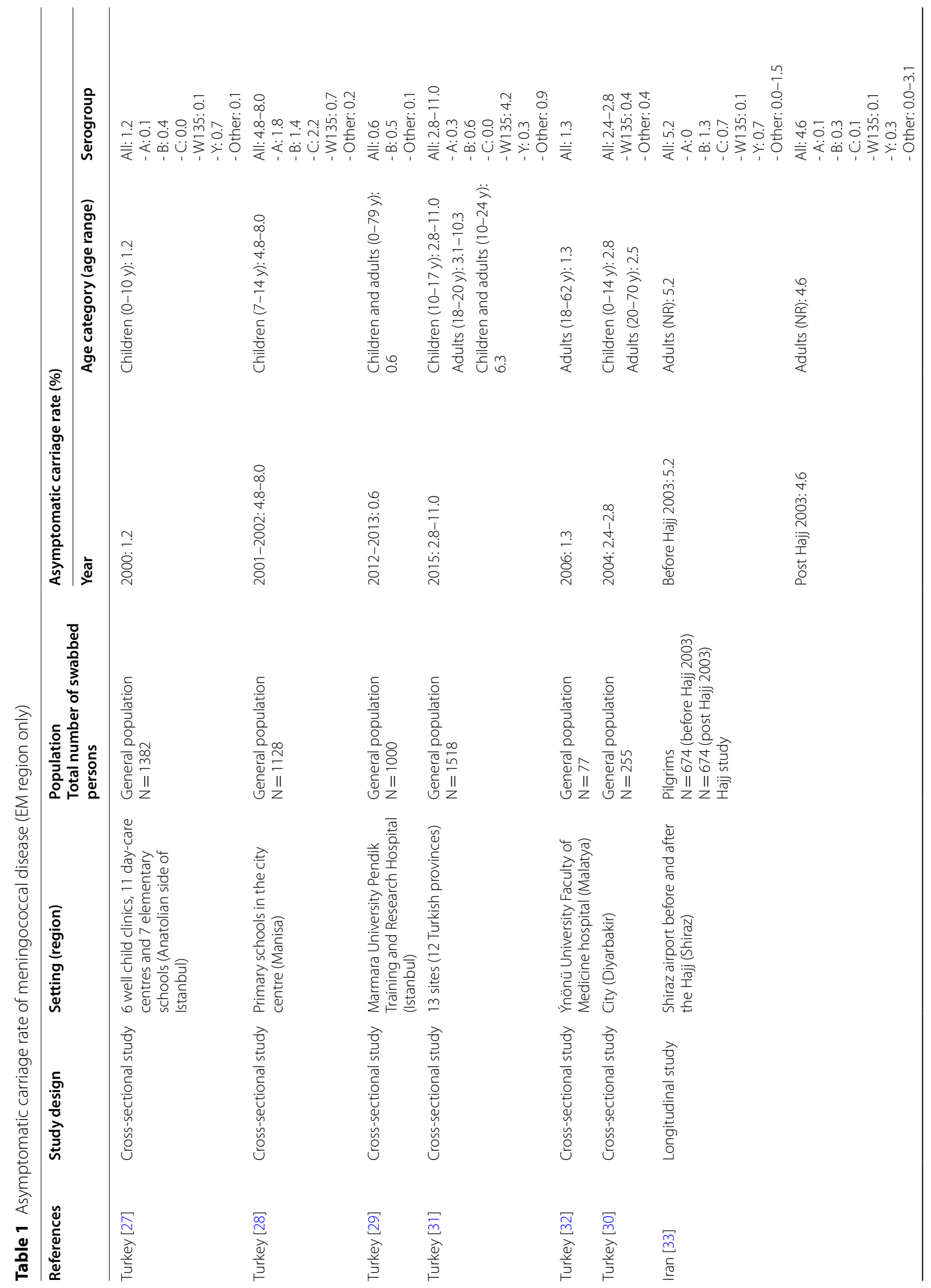




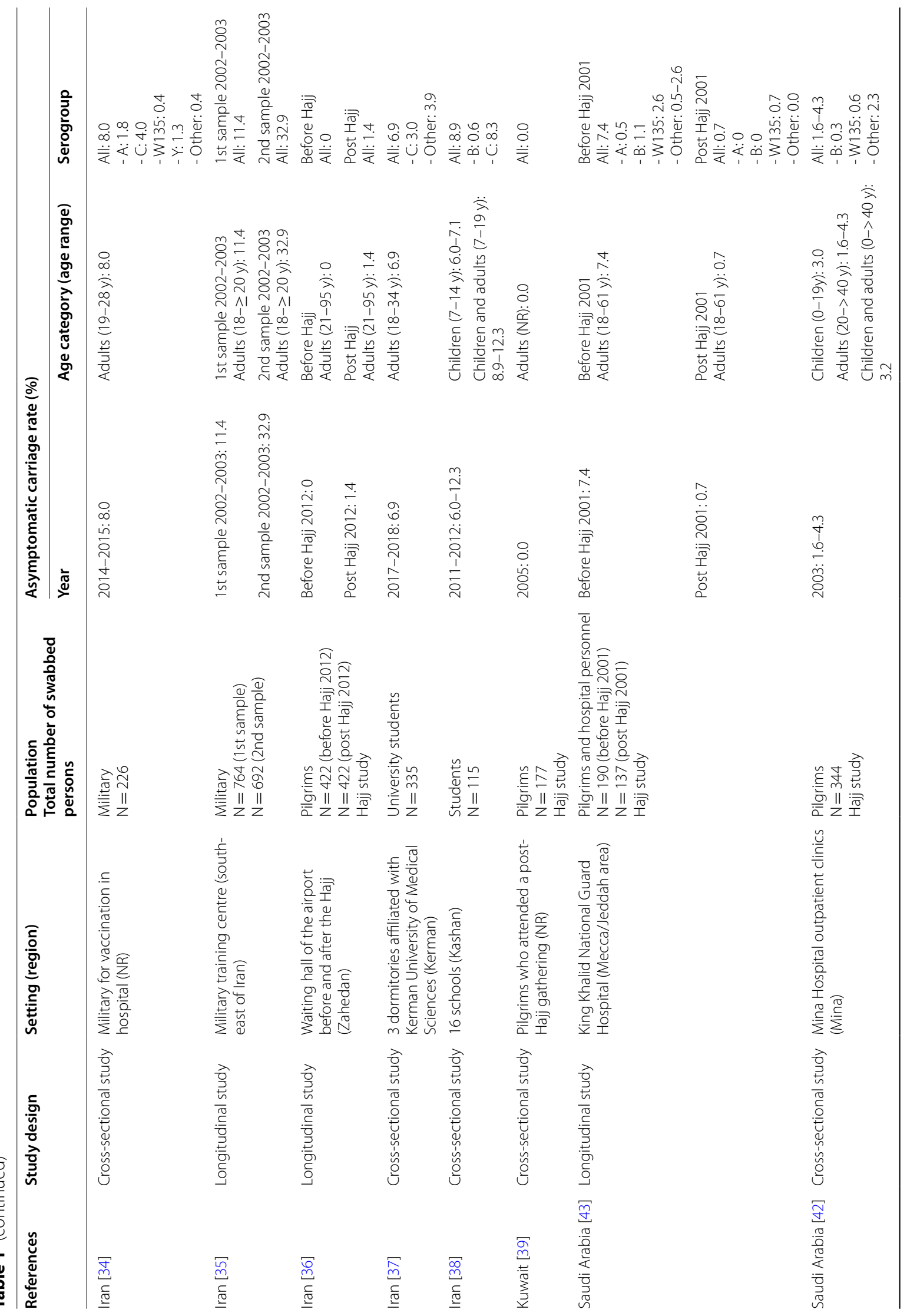




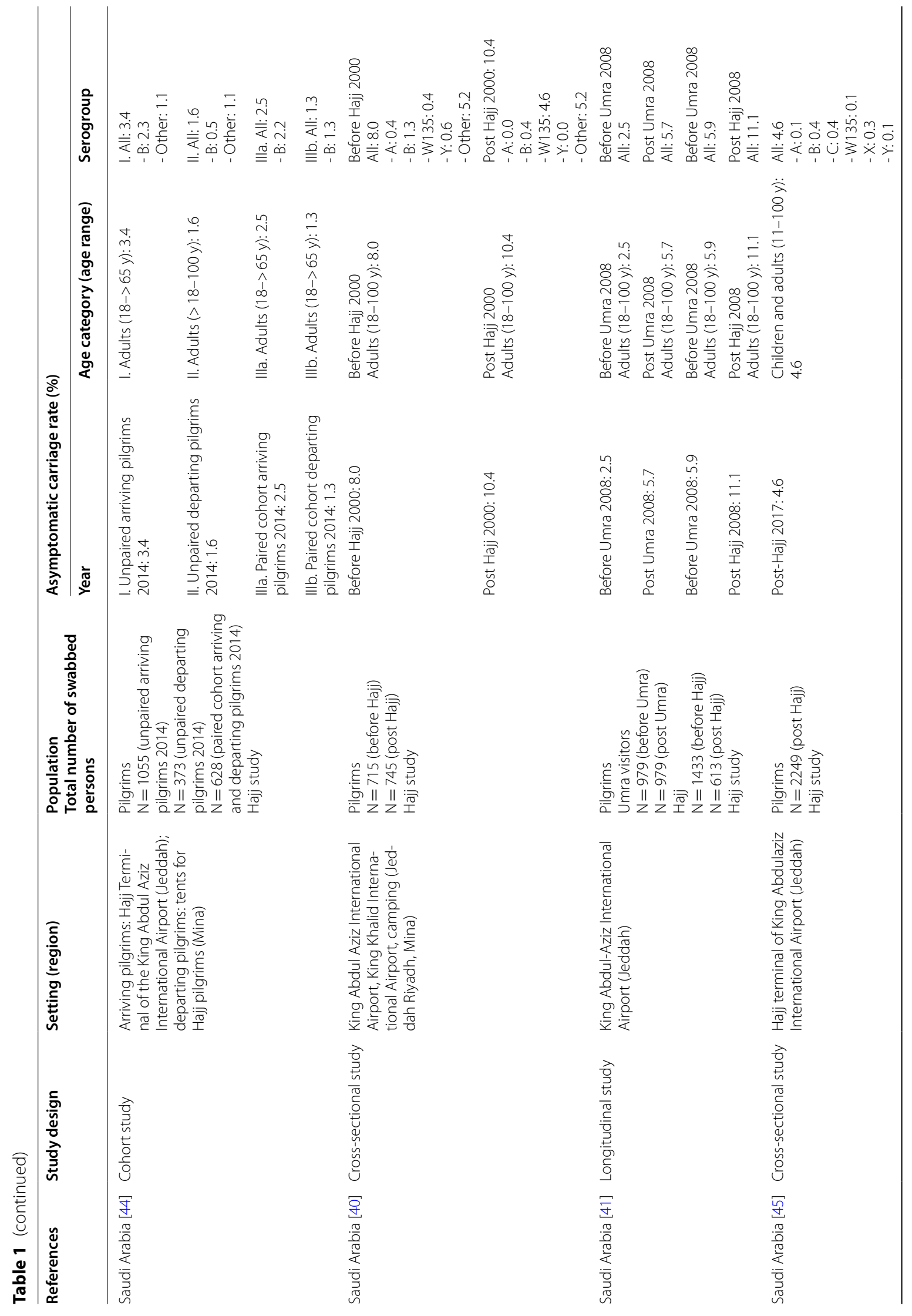




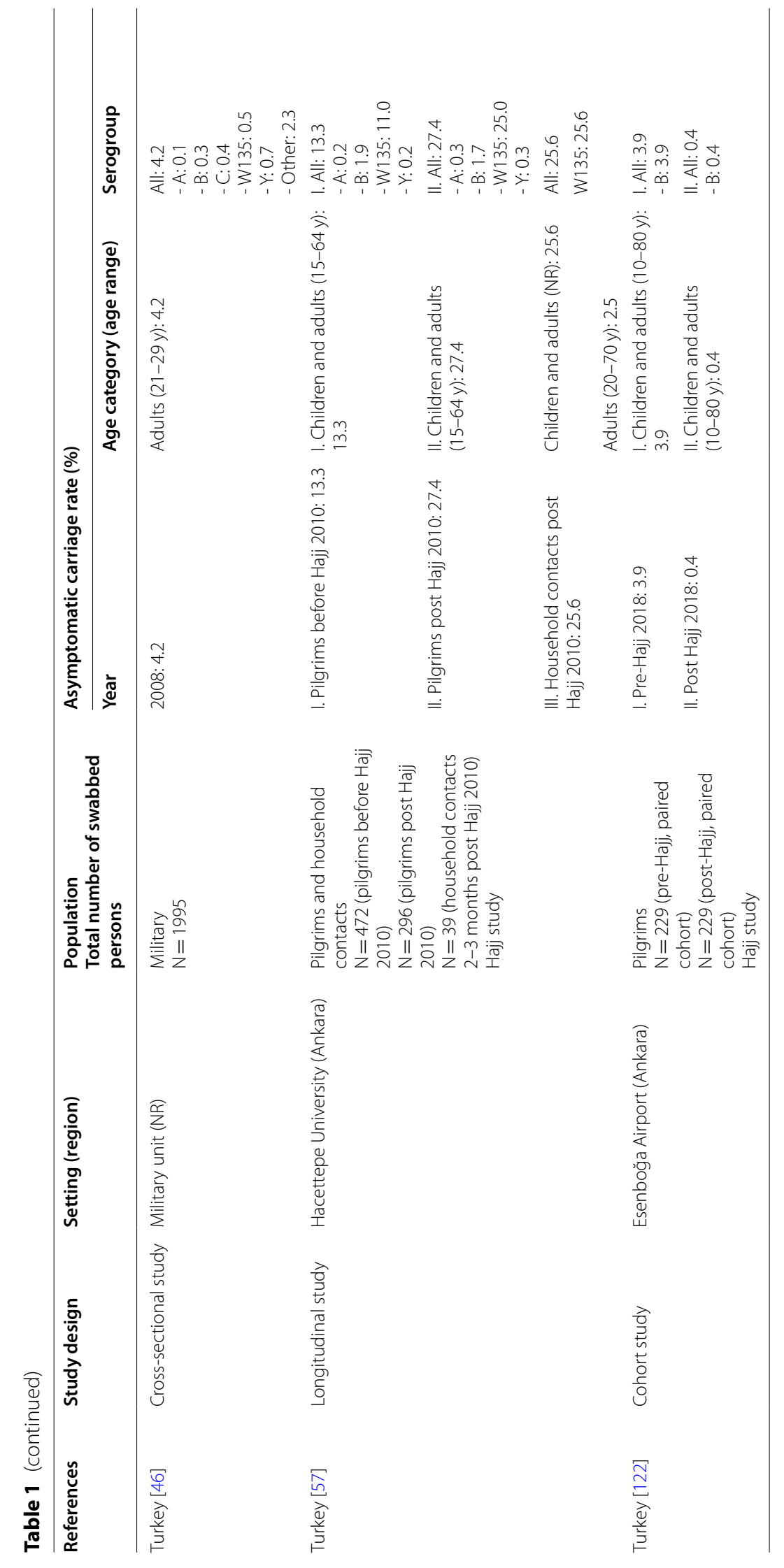


Turkey $(n=3)$ [57-59], and Yemen $(n=1)$ [60]. For the NA region, IMD incidence data were available for Egypt $(\mathrm{n}=2)$ [61, 62], Morocco $(\mathrm{n}=1)$ [63], and Tunisia $(\mathrm{n}=1)$ [64]. Age ranges were not clearly defined in many studies (e.g. children and adults [0-100 years]; Table 2).

Studies in the EM region included data collected between 1987 and 2018. The majority of studies did not differentiate incidence by serogroup. IMD incidence in the general population ranged from 0 to $19.7 / 100,000$ in children aged between 0 and 5 years in Saudi Arabia (Medina) in 1999-2001 [53], and from 8.8 to 20.5/100,000 in children aged between 0 and 5 years in Yemen (Sana'a) in 2000 [60]. In the remaining studies reporting on incidence in children in the general population, all were from Turkey. Incidence ranged from $0.3 / 100,000$ up to $0.9 / 100,000[58,59]$ between 2013 and 2016 in two studies, and fell from $1.9 / 100,000$ in 2005-2006 to $0.6 / 100,000$ in 2014 in another study [57]. The incidence of IMD in children and adults in the general population across the EM region ranged from 0.12/100,000 (Qatar; 2002) [52] to 2.0/100,000 (Saudi Arabia) [56] between 1987 and 2013 [49-52, 55, 56]. Incidence was 0.6/100,000 [50] in a military population in Iran (2000-2004) and ranged from 5.8 to $8.9 / 100,000$ in a study of pilgrims in Saudi Arabia in 2000 [54].

For the NA region, studies included incidence data collected between 1967 and 2018, all in the general population. IMD incidence in children only (aged between 0 and 18 years) was reported at 1.5/100,000 [64] in one study in Tunisia in 2014. Data for children and adults was available from two Egyptian studies and one Moroccan study, with incidence ranging from $0.1 / 100,000$ [61] to $3.75 / 100,000$ [63]. Data from the grey literature included a report from the Ministry of Health of the Kingdom of Saudi Arabia. This source reported an overall incidence of $0.02-0.03 / 100,000$ persons in 2017, rising very slightly from 0.01 in 2013 [65]. A World Health Organization (WHO) consultation from 2001 also reported on the number of meningococcal disease cases in Saudi Arabia over time, with the number of annual cases rising from $<20$ in 1995 to 253 in 2000 [66].

\section{Serogroup distribution}

There were more studies available on serogroup distribution from the EM region versus the NA region. Data were available from Iran $(n=2)[67,68]$, Kuwait $(n=1)$ [51], Qatar $(\mathrm{n}=1)$ [69], Saudi Arabia $(\mathrm{n}=6)$ [54-56, 70-72], and Turkey $(\mathrm{n}=8)$ [57-59, 73-77], in the EM region (spanning 1987-2018), and from Egypt $(\mathrm{n}=3)$ $[61,78,79]$, Morocco $(n=6)$ [80-85], and Tunisia $(n=6)$ [64, 86-90], in the NA region (spanning 1977-2019). Serogroups A, B and W were most frequently reported in the EM region, while $\mathrm{B}$ and $\mathrm{C}$ serogroups were most frequently reported in the NA region.

\section{CFR data}

CFR data were available in 27 studies in the EM region (Iran $\mathrm{n}=4$, [50, 67, 91, 92]; Kuwait $\mathrm{n}=3$, [51, 93, 94]; Pakistan $n=2$, [95, 96]; Qatar $n=2$, [52, 69]; Saudi Arabia $\mathrm{n}=4,[53-55,71]$; Turkey $\mathrm{n}=10,[57-59,74,76$, 97-101]; and Yemen $n=2,[60,102])$ and five studies in the NA region (Egypt $n=3,[62,78,79]$; Morocco $n=1$, [63] and Tunisia $n=1,[89]$ ); one multi-country study spanned both regions [103]. Data were collected between 1987 and 2018. Data on sample sizes for each study can be found in Additional file 1: Table S1. CFRs in the general population were very heterogeneous across the EM region; however, the majority were below 50\% (Fig. 2). Based on the more limited dataset from the NA region $(\mathrm{n}=5$; studies predominantly based in Egypt), rates ranged from 13.4\% (Egypt [62]) to 31.0\% (Morocco [63]) between 1997 and 2018. Reported CFRs in the EM region were generally lower than $25 \%$ in children in the general population, with only one study reporting a CFR value greater than 25\% (43.8\%; Turkey [101]). CFRs varied more widely in adults in the general population, with the majority falling between approximately $5 \%$ and $50 \%$. In the NA region, the CFR ranged from $17.7 \%$ [89] to $23.0 \%$ [79] in children and from $13.4 \%$ [62] to $31.0 \%$ [63] in mixed populations of children and adults. Data from the multi-country study reported CFRs ranging from $5.7 \%$ to $6.2 \%$ between 2004 and 2010 in the general population (5.7\% in children only [aged $0-5$ years] and $5.9-6.2 \%$ in children and adults) [103].

Four studies in the EM region provided data on CFRs in risk groups (military $n=1$ [50] and pilgrims $n=3[54$, $55,71]$ ). CFR data from the military population (based in Iran) ranged from 0 to $50.0 \%$ between 2000 and 2004, [50] while data from the pilgrim population (all studies in Saudi Arabia) showed a CFR range from $0.0 \%[55,71]$ to $57.9 \%$ [71]. Data from the previously-mentioned WHO consultation reported a CFR of $27.7 \%$ among IMD cases in Saudi Arabia in 2001, with a CFR of 32.1\% observed in the subset of cases associated with the Hajj [66].

\section{Objective 3: IMD presentation and management Clinical presentation}

Five studies in the EM region (Iran $n=1$ [91]; Saudi Arabia $\mathrm{n}=1$ [71]; and Turkey $\mathrm{n}=3[97,100,101])$ and two studies in the NA region (Morocco $n=1$ [104] and Tunisia $n=1$ [89]) had data on clinical presentation. The majority of studies were in children aged 0-14 years $(\mathrm{n}=6)$, and the study in Saudi Arabia was in adults aged $18-80$ years [71]. The most common presentations across both regions were meningitis $(12.5 \%$ [101]-63.8\% [71]), 


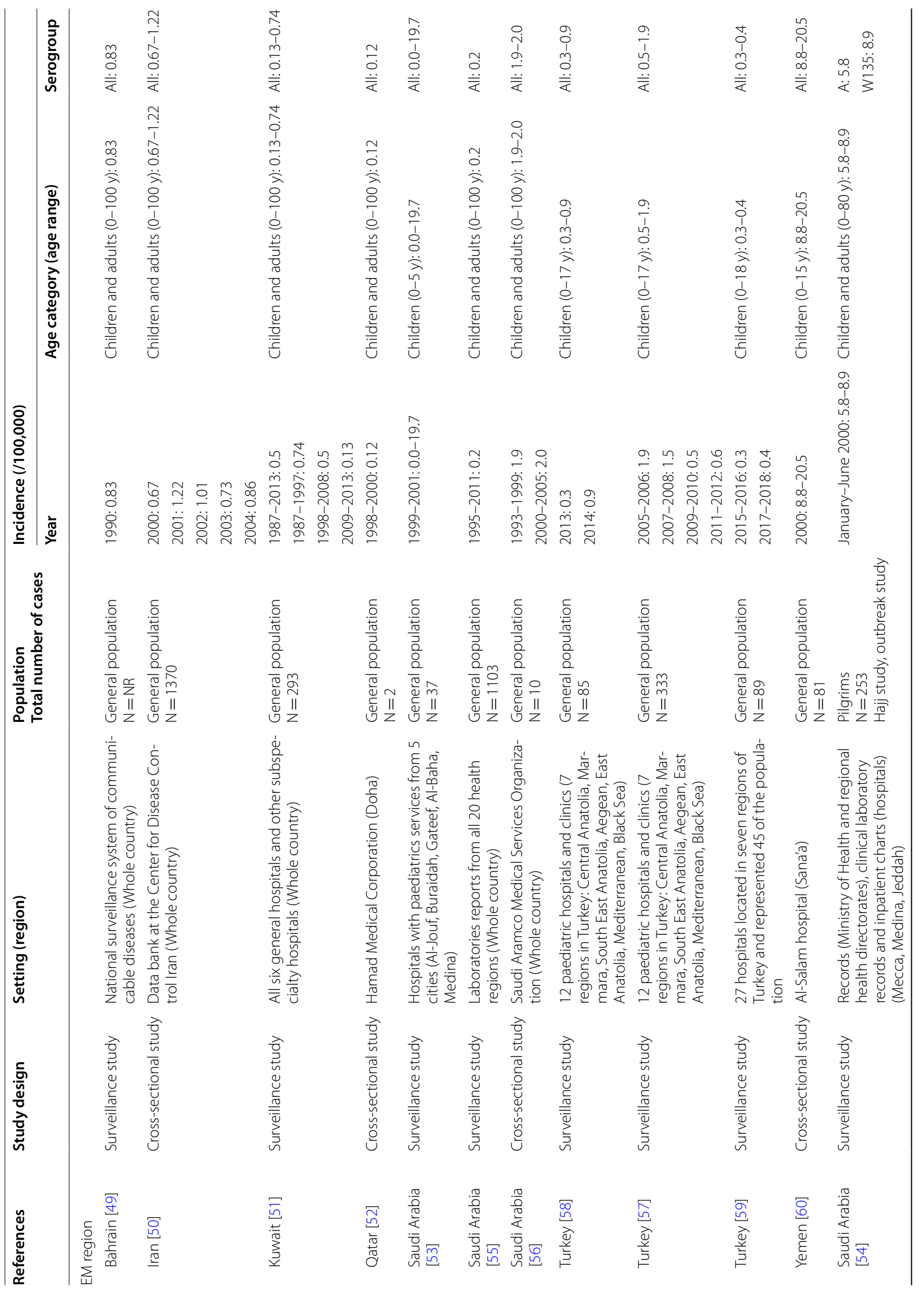




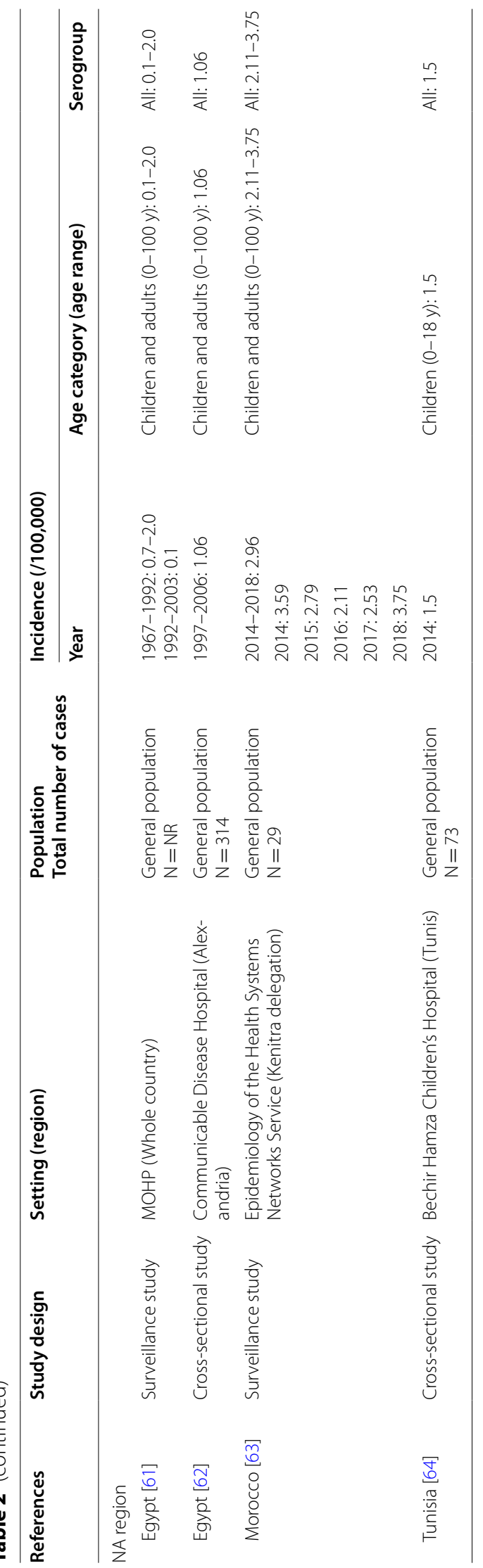




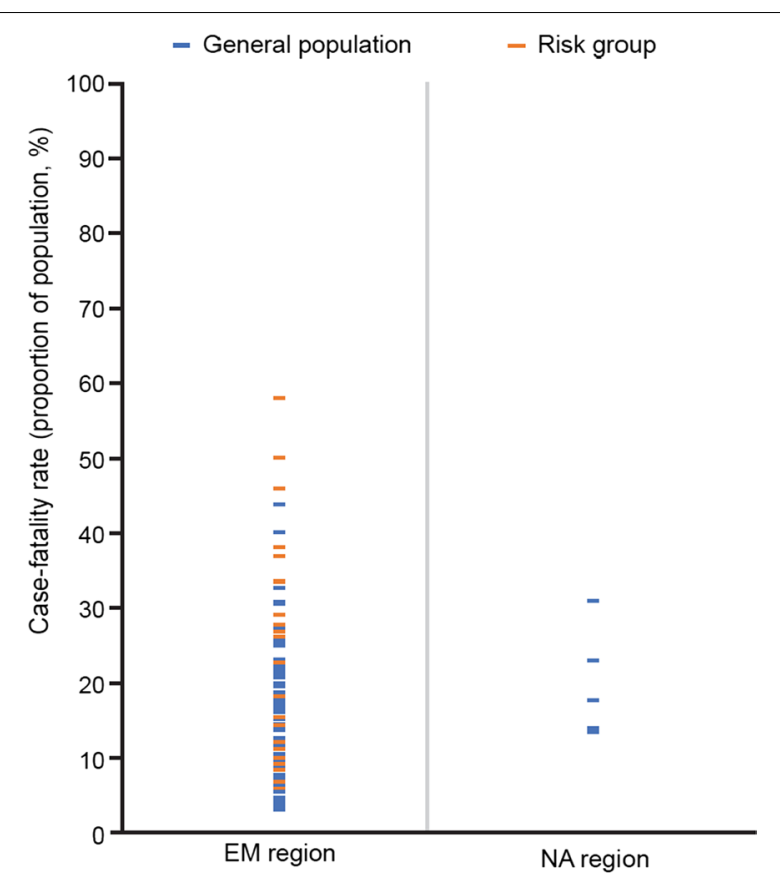

Fig. 2 Reported case-fatality rate (general population and risk groups). EM Eastern Mediterranean region, NA North Africa region. Countries providing data for EM region: Iran, Kuwait, Pakistan, Qatar, Saudi Arabia, Turkey and Yemen. Countries providing data for NA region: Egypt and Tunisia

followed by meningococcaemia (7.6\% [71]-56.3\% [101]), and meningitis plus meningococcaemia (11.4\% [104]$36.2 \%[71])$.

\section{Hospitalisation}

Six studies in the EM region (Kuwait $\mathrm{n}=1$ [94]; Pakistan $n=1$ [105]; Saudi Arabia $n=2$ [53, 54]; and Turkey $\mathrm{n}=2[97,101]$ ) and two studies in the NA region (Egypt $\mathrm{n}=2[62,78]$ ) included data on hospitalisation. In the EM region studies in children, the mean/median length of hospital stay (LOS) ranged from 9.8 [101] to 21.9 [97] days. Intensive care unit (ICU) admission was required for $30.0 \%$ of cases in Kuwait [94] and 5.4\% of cases in Saudi Arabia [53], and mean ICU LOS ranged from 5.0 [53] to 7.8 days [97]. In children and adults in Saudi Arabia, $24.1 \%$ required ICU admission, with $64.7 \%$ of this group requiring ICU care for more than 1 day [54]. Studies from Egypt (in children and adults) reported that LOS was generally lower than 15 days (median LOS 10 days [78], mean LOS 14.7 days [62]).

\section{Symptoms, complications and sequelae}

Data were collected on acute symptoms, admission and acute complications, and post-discharge complications and sequelae; full information is provided in Table 3. Since outcomes were not well defined in the majority of included articles, it was not possible to provide a list of definitions for these outcomes.

Six studies from the EM region (Iran $\mathrm{n}=2[91,106]$; Qatar $n=1$ [69]; Saudi Arabia $n=1$ [71]; and Turkey $\mathrm{n}=2[97,107])$ and two studies from the NA region (Egypt $\mathrm{n}=1$ [78] and Morocco $\mathrm{n}=1$ [104]) included information on acute symptoms of meningococcal disease. Commonly observed symptoms across both regions included rash, seizure, headache, stiff neck and fever. No particular pattern was observed for symptoms or age groups. Serogroup was infrequently reported in these studies and so it was not possible to correlate serogroups with symptoms. Data on complications at admission and acute complications were available from three studies (all in children), of which two were in the EM region (Iran $n=1$ [91]; Turkey $n=1$ [97]), and one in the NA region (Morocco $n=1$ [104]). Septic shock was reported in approximately $40 \%$ of patients in the studies from the EM region, while hemodynamic disorder/sepsis were reported in over half of patients in the study from the NA region. Data on post-discharge complications and sequelae were available from eight EM region studies (Kuwait $\mathrm{n}=2[93,94]$; Qatar $\mathrm{n}=2[52,69]$; Saudi Arabia $\mathrm{n}=2[53$, $71]$; and Turkey $\mathrm{n}=2[98,99]$ ) and two NA region studies (Egypt $\mathrm{n}=1$ [78] and Tunisia $\mathrm{n}=1$ [89]). The majority of studies in the EM region reported non-specified sequelae; there was little overlap across studies in terms of specific reported events for either region.

\section{Antibiotic treatment}

Three studies in Turkey and one in Qatar had data on antibiotic treatment; no studies were retrieved from the NA region. The Turkish studies focused on antibiotic use in children only $[74,97,100]$, while the Qatari study included data from a mixed population of children and adults aged 0-80 years [69]. Ceftriaxone monotherapy was prescribed to 53.8 [97]-100\% [100] of patients in all studies in Turkey, and in combination with vancomycin in one study (40.0\% of cases) [74]. Penicillin was used by $9.8 \%$ of patients in another study [97]. In the Qatari study, ceftriaxone was prescribed in $80.0 \%$, and penicillin in $20.0 \%$ of cases [69].

\section{Prophylaxis or vaccination of persons in close contact}

No studies in the EM or NA region reported on prophylaxis or vaccination of persons in close contact with a known case of meningococcal infection.

\section{Discussion}

This systematic review identified that high-risk groups such as military personnel, pilgrims and students remain a significant reservoir of asymptomatic meningococcal carriage in the EMNA region, with few studies specifying 
Table 3 Symptoms, complications and sequelae

\begin{tabular}{|c|c|c|c|c|c|c|c|c|}
\hline \multicolumn{9}{|c|}{ a) Acute symptoms } \\
\hline \multirow{2}{*}{$\begin{array}{l}\text { Region } \\
\text { Country }\end{array}$} & \multicolumn{6}{|l|}{ EM } & \multicolumn{2}{|l|}{ NA } \\
\hline & Iran [106] & Iran [91] & Qatar [69] & Turkey [97] & Turkey [107] & $\begin{array}{l}\text { Saudi Arabia } \\
\text { [71] }\end{array}$ & Egypt $[78]^{\mathrm{b}}$ & Morocco [104] \\
\hline Population type & GP & GP & GP & GP & GP & P & GP & GP \\
\hline $\begin{array}{l}\text { Number of } \\
\text { patients in } \\
\text { study }\end{array}$ & 3 & 68 & 25 & 65 & 7 & 105 & 203 & 35 \\
\hline Date range, year & 2009-2011 & 1992-2002 & 1992-2008 & $2000-2005$ & 1995-2003 & $\begin{array}{l}\text { February-April } \\
2000\end{array}$ & 1998-2004 & 2011-2013 \\
\hline Age range, year & $\begin{array}{l}\text { Children } \\
(0.5-10)\end{array}$ & Children (0-13) & $\begin{array}{l}\text { Children, adults } \\
(0-68)\end{array}$ & $\begin{array}{l}\text { Children } \\
(0.5-10)\end{array}$ & $\begin{array}{l}\text { Children, adults } \\
(15-60)\end{array}$ & Adults (18-80) & $\begin{array}{l}\text { Children, adults } \\
(0-75)\end{array}$ & Children (0-13) \\
\hline \multicolumn{9}{|l|}{ Symptoms } \\
\hline $\begin{array}{l}\text { Proportion } \\
\text { of patients } \\
\text { experiencing } \\
\text { acute symp- } \\
\text { toms (\%) }\end{array}$ & $0.0-100$ & $8.8-64.7$ & $4.0-80.0$ & 7.7-95.4 & 71.4 & 28.6 & $16.0-79.0$ & $5.7-65.7$ \\
\hline Stiff neck & 100 & 55.9 & 52.0 & & & & 79 & \\
\hline Rash & 0 & 64.7 & 28.0 & & 71.4 & 28.6 & 16 & 65.7 \\
\hline Fever & 66.7 & & 80.0 & 95.4 & & & & \\
\hline $\begin{array}{l}\text { Meningeal } \\
\text { irritation } \\
\text { syndrome }\end{array}$ & 66.7 & & & & & & & \\
\hline Seizure & 66.7 & 8.8 & $4.0-12.0$ & 7.7 & & & & 11.4 \\
\hline Headache & & 55.9 & 48.0 & & & & 66.0 & 31.4 \\
\hline Vomiting & & & 56.0 & & & & & 40.0 \\
\hline $\begin{array}{l}\text { Altered con- } \\
\text { sciousness }\end{array}$ & & & 48.0 & 27.7 & & & & \\
\hline Diarrhoea & & & & 9.2 & & & & 11.4 \\
\hline Purpura & & & & 92.3 & & & & \\
\hline Photophobia & & & & & & & 37 & \\
\hline Neck pain & & & & & & & & 17.1 \\
\hline $\begin{array}{l}\text { Abdominal } \\
\text { pain }\end{array}$ & & & & & & & & 5.7 \\
\hline Lethargy & & & & & & & & 48.6 \\
\hline Irritability & & & & & & & & 8.6 \\
\hline
\end{tabular}

\section{b) Complications at admission and acute complications}

\begin{tabular}{|c|c|c|c|}
\hline Region & EM & & NA \\
\hline Reference & Iran [91] & Turkey [97] & Morocco [104] \\
\hline Population type & GP & GP & GP \\
\hline Number of patients in study & 68 & 65 & 35 \\
\hline Date range, year & 1992-2002 & $2000-2005$ & $2011-2013$ \\
\hline Age range, year & Children (0-13) & Children (0.5-10) & Children (0-13) \\
\hline \multicolumn{4}{|l|}{ Complications at admission and acute complications } \\
\hline $\begin{array}{l}\text { Proportion of patients experiencing complications at admis- } \\
\text { sion and acute complications (\%) }\end{array}$ & $2.9-38.2$ & $3.1-38.5$ & $11.4-54.3$ \\
\hline Septic shock & 38.2 & 38.5 & \\
\hline Conjunctivitis & 2.9 & & \\
\hline Pericarditis & 2.9 & & \\
\hline Myocarditis & & 4.6 & \\
\hline Purpura fulminans & & 4.6 & \\
\hline Acute renal failure & & 3.1 & \\
\hline
\end{tabular}


Table 3 (continued)

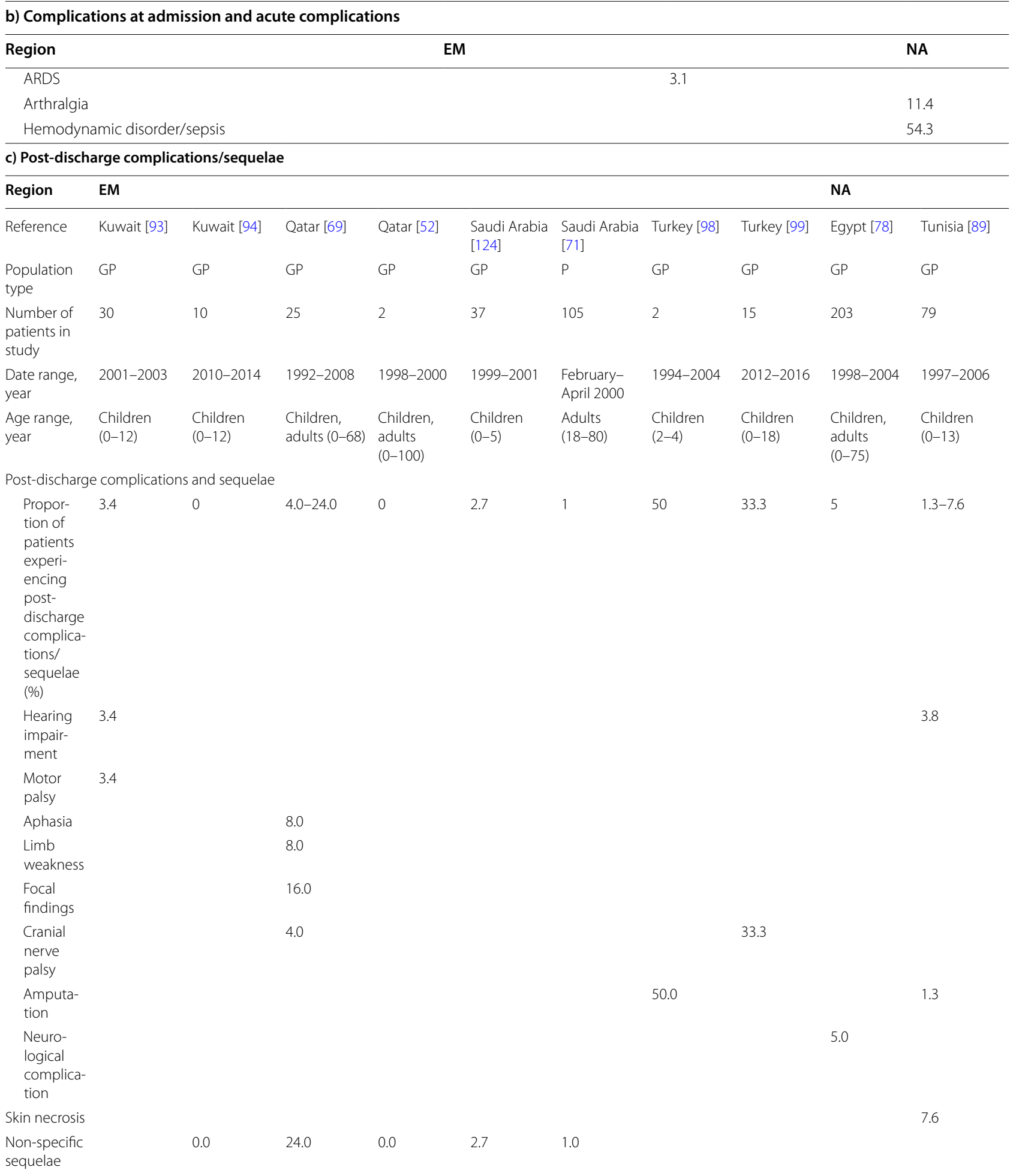

All studies are cross-sectional unless otherwise stated

ARDS acute respiratory distress syndrome, EM Eastern Mediterranean region, GP general population, NA North Africa region, $P$ pilgrims

${ }^{a}$ Meningeal irritation syndrome encompasses Kernig's sign and Brudzinski's sign [123]

${ }^{\mathrm{b}}$ Surveillance study 
asymptomatic carriage by age group. In general, more studies were retrieved from the EM region compared with the NA region. Incidence of IMD in the EMNA region was poorly defined, with data only available for $7 / 15$ countries in the EM region and 3/5 countries in the NA region. CFRs associated with IMD were heterogenous, and few data were available on CFRs in key risk groups (including household contacts, military personnel, pilgrims and students). Data were also heterogenous for complications and sequelae. Approximately one-third of patients were admitted to the ICU, and LOS was generally below 3 weeks (in hospital or in the ICU). Relatively few studies reported data on antibiotic treatment, which were reported in the EM region only. In studies that did provide data on antibiotic use, ceftriaxone was commonly used. Information on antibiotic resistance was not captured in this study. Furthermore, no studies in the EMNA region reported on prophylaxis or vaccination of persons in contact with known cases of infection, or on economic impact and evaluation. These data gaps indicate a pressing need for more studies from the region, ideally focusing on similar study outcomes for ease of comparison.

Results from a recent meta-analysis (spanning 20122017) indicate that N. meningitidis accounts for $9 \%$ and $36 \%$ of all bacterial meningitis cases in Eastern Mediterranean and African regions, respectively [108]. Furthermore, the burden of IMD in the Eastern Mediterranean Regional Office (EMRO) region is second highest after the African meningitis belt (bacterial meningitis is also second highest in the EMRO region compared with the African region), with several countries (where data exists) reporting moderate/high endemic rates [45, 109, 110]. In our review, the most comprehensive IMD incidence data were available for Saudi Arabia. There were no EM regional IMD incidence data from Bahrain, Iraq, Jordan, Lebanon, Oman, Palestinian Territories, Syria, Turkey, and the United Arab Emirates.

It is interesting to compare our findings with those from other regions. Data from various sources showed that the overall incidence of IMD was $0.6 / 100000 \mathrm{popu}-$ lation in Europe (in 2017), 0.13/<1.0 per 100,000 population in the USA/Canada (2013/2015), 0.16-0.8/100000 population in Latin America (2012-2018), 1.5/100000 population in Australia (2013-2017), 1.8/100000 population in China (2000-2010), <1.0/100000 population in Asia (2020; excluding China) and $<0.2 / 100000$ population overall in the Asia-Pacific region (2020) [17, 111114]. Incidence in the EM region in the current study ranged from 0 to 20.5/100,000 persons (based on data from seven countries). In contrast, incidence in the NA region ranged from 0.1 to $3.75 / 100000$ persons (based on data from Egypt, Morocco and Tunisia). The incidence of
IMD was highest in infants and young children in several regions (e.g. Europe, USA/Canada, Latin America) which is similar to data from EMNA presented here [112].

IMD CFRs are often high in the EMNA region with rates up to $50 \%$ reported, and many studies reporting rates between 5 and $25 \%$. It is possible that the high CFRs observed in the EMNA region could potentially reflect inadequate or delayed treatment [1]. CFRs elsewhere vary, both by region and by age group. For example, overall CFR was 10\% in Europe in 2017 and increased to $18 \%$ in cases in people aged 65 years and over [17]. Other countries also report high CFRs (e.g. China [33\% between 2000 and 2010] and Brazil [20.7\% between 2005 and 2011]) [111, 114].

Globally, the IMD CFR can be higher in infants than older children, but is highest in those $\geq 65$ years of age [15]. Although data on CFRs in children and adults were identified in the EM and NA regions, it is difficult to make comparisons between age groups, especially when considering heterogeneity in study design. Furthermore, given the importance of age for the epidemiology of IMD, it is notable that patients were not routinely separated by age in the studies included here.

In our study, serogroups A, B and W were common in the EM region, and the $\mathrm{B}$ and $\mathrm{C}$ serogroups were common in the NA region. This is in line with findings from a recent systematic review, which reported that $N$. meningitidis serogroup $B$ is the predominant cause of IMD in various parts of Europe, North America, Latin America and the Western Pacific, while serogroups $C$ and W were responsible for a substantial proportion of IMD cases in large parts of Africa and Latin America. It should also be noted that serogroups W, A and X were reported as causes of IMD in many countries in the African meningitis belt $[115,116]$.

The WHO has also identified the need for awareness of meningococcal disease burden and development of surveillance systems to characterise national epidemiology in all countries $[14,117]$. In particular, the WHO global roadmap for defeating meningitis by 2030 recommends that all countries should design and implement a surveillance system which allows integration of public/ private healthcare and also covers key components such as epidemiology, laboratory and data management [109]. Evaluation of mass vaccine programmes in countries in the African meningitis belt is also recommended [117]. Introduction of vaccines specific to particular serogroups has previously led to a reduction in the burden associated with those serogroups in the African meningitis belt and Europe [17, 112, 118], illustrating that vaccination programmes may change the burden and molecular epidemiology of IMD. However, migration dynamics may also influence IMD burden and epidemiology in the EMNA 
region, due to the increased risk of IMD transmission during the Umrah and Hajj pilgrimages [11, 13, 14, 20]. These dynamics render the regional situation even more complex, and provide at least a partial explanation as to why the WHO goals of increased awareness/improved surveillance systems are still far from being met in the EMNA region.

It has long been known that vaccination has important benefits in terms of protecting individuals against IMD, lowering the carriage rates of $N$. meningitidis in the community and providing herd protection for non-vaccinated individuals [119]. Since the 2000s, these Hajj-related outbreaks have been reduced through local vaccination programmes for pilgrims with the quadrivalent meningococcal vaccine in Saudi Arabia [13]. Saudi Arabia also now demands proof of recent meningococcal vaccination (specifying a quadrivalent vaccine $[\mathrm{ACYW}]$ ) as a visa requirement for international pilgrims travelling to these gatherings $[11,120]$. However, IMD burden in the region remains high and so further action is needed.

These data highlight gaps in our current understanding of the epidemiology and disease burden of IMD in the EMNA region [24]. This situation contrasts with the much stronger IMD surveillance data available for areas such as Europe [17] and the African meningitis belt [24], and may be linked to lack of systems or resources for disease surveillance within the EMNA region. It should be noted that the general lack of effective surveillance in the EMNA region occurs even though, as in Europe, IMD is a notifiable disease. To improve surveillance in this region, the WHO has funded the Invasive Bacterial Vaccine Preventable Diseases Laboratory Network, including a regional reference laboratory in Egypt and a site laboratory in Yemen; however, other EMNA countries in this study do not appear to have laboratories associated with this network [121]. In addition, despite some EMNA countries having national surveillance networks and laboratories with the ability to serogroup IMD samples [24, 115], there is still a general lack of published epidemiological studies from these countries. These findings suggest the need for a standardised global approach to IMD reporting to improve the epidemiological evidence base and address the high disease burden.

The strengths of this systematic literature review include that it was based on broad search terms and included articles in all languages and reports on data amassed over an 18-year period. Limitations include the lack of consistent data availability. In addition, the heterogeneity of the design/methodology of the selected studies and the resulting data means that it is difficult to compare outcomes across studies. As a result, the findings from this search may not reflect the true disease burden and serogroup distribution; therefore, further data on the epidemiology and disease burden of IMD in the EMNA region are needed.

In conclusion, our systematic review identifies the crucial need to increase national surveillance systems and laboratory capacity in this region in order to improve the quality of data and reporting. There is also a pressing requirement for conducting further research on the consequences and burden of meningitis and meningococcaemia. This will allow us to better understand their epidemiology and design health policies to reduce the subsequent burden on regional healthcare systems.

\section{Abbreviations}

AMEE: Asia, Middle East and Eurasia; CFR: Case-fatality rate; EM: Eastern Mediterranean; EMRO: Eastern Mediterranean Regional Office; HTA: Health technology assessment; ICU: Intensive care unit; IMD: Invasive meningococcal disease; LOS: Length of stay; MACV: Meningococcal A conjugate vaccine; NA: North Africa; PRISMA: Preferred Reporting Items for Systematic Reviews and Meta-Analyses; WHO: World Health Organization.

\section{Supplementary Information}

The online version contains supplementary material available at https://doi. org/10.1186/s12879-021-06781-6.

Additional file 1. Additional information on methodology and data per region/country. PRISMA statement, details of systematic review strategy, total number of cases per study and associated CFR, Countries with/without data for each objective.

\section{Acknowledgements}

Editorial assistance was provided by Hanna Mourad-Agha, Ph.D., of Fishawack Communications Ltd, UK, funded by Sanofi Pasteur.

\section{Authors' contributions}

AOS and FKB oversaw study design, data collection and analysis, and all authors were involved in data interpretation and drafting the manuscript. All authors read and approved the final manuscript.

Funding

This work was funded by Sanofi Pasteur.

Availability of data and materials

The datasets used and/or analysed during the current study are available from the corresponding author on reasonable request.

\section{Declarations}

Ethics approval and consent to participate

Not applicable.

\section{Consent for publication}

Not applicable.

\section{Competing interests}

$A G D$ and $A A$ are employees of Sanofi Pasteur and may hold shares and/ or stock options in the company. AOS and FKB are employees of Pallas. MC reported no conflicts of interest relevant to the manuscript. 


\section{Author details}

'Sanofi Pasteur, Dubai, UAE. ${ }^{2}$ Pallas, Rotterdam, the Netherlands. ${ }^{3}$ Faculty of Medicine, Hacettepe University, Ankara, Turkey.

Received: 30 November 2020 Accepted: 6 October 2021 Published online: 22 October 2021

\section{References}

1. Nadel S, Ninis N. Invasive meningococcal disease in the vaccine era. Front Pediatr. 2018:6:321.

2. Christensen H, May M, Bowen L, Hickman M, Trotter CL. Meningococcal carriage by age: a systematic review and meta-analysis. Lancet Infect Dis. 2010;10(12):853-61.

3. MacLennan J, Kafatos G, Neal K, Andrews N, Cameron JC, Roberts R, Evans MR, Cann K, Baxter DN, Maiden MC, et al. Social behavior and meningococcal carriage in British teenagers. Emerg Infect Dis. 2006;12(6):950-7.

4. van Deuren M, Brandtzaeg P, van der Meer JW. Update on meningococcal disease with emphasis on pathogenesis and clinical management. Clin Microbiol Rev. 2000;13(1):144-66 (table of contents)

5. Gabutti G, Stefanati A, Kuhdari P. Epidemiology of Neisseria meningitidis infections: case distribution by age and relevance of carriage. J Prev Med Hyg. 2015;56(3):E116-120

6. Cooper LV, Kristiansen PA, Christensen H, Karachaliou A, Trotter CL. Meningococcal carriage by age in the African meningitis belt: a systematic review and meta-analysis. Epidemiol Infect. 2019;147:e228.

7. Rouphael NG, Stephens DS. Neisseria meningitidis: biology, microbiology, and epidemiology. Methods Mol Biol. 2012;799:1-20.

8. Loenenbach AD, van der Ende A, de Melker HE, Sanders EAM, Knol MJ. The clinical picture and severity of invasive meningococcal disease serogroup W compared with other serogroups in the Netherlands, 2015-2018. Clin Infect Dis. 2020;70(10):2036-44.

9. Stinson C, Burman C, Presa J, Abalos M. Atypical presentation of invasive meningococcal disease caused by serogroup W meningococci. Epidemiol Infect. 2020;148:e12.

10. Batista RS, Gomes AP, Dutra Gazineo JL, Balbino Miguel PS, Santana LA, Oliveira L, Geller M. Meningococcal disease, a clinical and epidemiological review. Asian Pac J Trop Med. 2017;10(11):1019-29.

11. Meningococcal disease. https://www.who.int/ith/diseases/meningococ cal/en/.

12. Meningococcal disease. Risk factors. https://www.cdc.gov/meningococ cal/about/risk-factors.html.

13. Yezli S, Assiri AM, Alhakeem RF, Turkistani AM, Alotaibi B. Meningococcal disease during the Hajj and Umrah mass gatherings. Int J Infect Dis. 2016:47:60-4

14. Meningococcal vaccines: WHO position paper, November 2011. https:// www.who.int/wer/2011/wer8647.pdf?ua=1. Accessed May 2020.

15. Pelton SI. The global evolution of meningococcal epidemiology following the introduction of meningococcal vaccines. J Adolesc Health. 2016:59(2 Suppl):S3-11.

16. Erlich KS, Congeni BL. Importance of circulating antibodies in protection against meningococcal disease. Hum Vaccines Immunother. 2012;8(8):1029-35.

17. Invasive meningococcal disease: annual epidemiological report for 2017. ECDC. https://www.ecdc.europa.eu/sites/default/files/docum ents/AER_for_2017-invasive-meningococcal-disease.pdf. Accessed May 2020

18. Presa J, Findlow J, Vojicic J, Williams S, Serra L. Epidemiologic trends, global shifts in meningococcal vaccination guidelines, and data supporting the use of MenACWY-TT vaccine: a review. Infect Dis Ther. 2019;8(3):307-33.

19. A trial to describe the immunogenicity and safety of 2 doses of bivalent rLP2086 (Trumenba) and a pentavalent meningococcal vaccine in healthy subjects $>=10$ to $<26$ years of age. NCT03135834. https://clini caltrials.gov/ct2/show/NCT03135834?term $=$ NCT03135834\&draw $=2 \&$ rank $=1$. Accessed June 2020.

20. Study to evaluate the lot to lot consistency of SIIPL meningococcal ACYWX conjugate vaccine and to compare its safety and immunogenicity with that of licensed meningococcal ACWY Vaccine Menactra ${ }^{\circledR}$ in healthy individuals 18-85 years of age (ACYWX-04). https://clinicaltr ials.gov/ct2/show/NCT04358731?term $=$ NCT04358731\&draw $=2 \&$ rank $=1$. Accessed June 2020.

21. Chang Q, Tzeng Y-L, Stephens DS. Meningococcal disease: changes in epidemiology and prevention. Clin Epidemiol. 2012:4:237.

22. GASTAT: Total number of pilgrims in $1439 \mathrm{H}$ Hajj season. General authority for Statistics, Kingdom of Saudi Arabia. https://www.stats.gov.sa/en/ news/280. Accessed June 2020.

23. Mustapha MM, Harrison LH. Vaccine prevention of meningococcal disease in Africa: major advances, remaining challenges. Hum Vaccines Immunother. 2018;14(5):1107-15.

24. Ceyhan M, Anis S, Htun-Myint L, Pawinski R, Soriano-Gabarro M, Vyse A. Meningococcal disease in the Middle East and North Africa: an important public health consideration that requires further attention. Int J Infect Dis. 2012;16(8):e574-582.

25. Borrow R, Caugant DA, Ceyhan M, Christensen H, Dinleyici EC, Findlow J, Glennie L, Von Gottberg A, Kechrid A, Vazquez Moreno J, et al. Meningococcal disease in the Middle East and Africa: findings and updates from the Global Meningococcal Initiative. J Infect. 2017;75(1):1-11.

26. Moher D, Liberati A, Tetzlaff J, Altman DG. Preferred reporting items for systematic reviews and meta-analyses: the PRISMA statement. Ann Intern Med. 2009;151(4):264-9.

27. Bakir M, Yagci A, Ulger N, Akbenlioglu C, Ilki A, Soyletir G. Asymtomatic carriage of Neisseria meningitidis and Neisseria lactamica in relation to Streptococcus pneumoniae and Haemophilus influenzae colonization in healthy children: apropos of 1400 children sampled. Eur J Epidemiol. 2001:17(11):1015-8.

28. Gazi H, Surucuoglu S, Ozbakkaloglu B, Alkcali S, Ozkutuk N, Degerli K, Kurutepe $\mathrm{S}$. Oropharyngeal carriage and penicillin resistance of Neisseria meningitidis in primary school children in Manisa, Turkey. Ann Acad Med Singapore. 2004;33(6):758-62.

29. Kadayifci EK, Merdan DG, Soysal A, Karaaslan A, Atıcı S, Durmaz R, Boran P, Turan I, Söyletir G, Bakır M. Prevalence of neisseria meningitidis carriage: a small-scale survey in Istanbul, Turkey. J Infect Dev Ctries. 2016;10(4):413-7.

30. Şahiner N, Akba E, Nar S, Esen B. Investigation of neisseria meningitidis carriage and its risk factors following a cluster of meningococcal disease in diyarbakir. Nobel Medicus. 2011;7(3):28-35.

31. Tekin RT, Dinleyici EC, Ceyhan M, Karbuz A, Salman N, Sutçu M, Kurugol Z, Balliel Y, Celik M, Hacimustafaoglu M, et al. The prevalence, serogroup distribution and risk factors of meningococcal carriage in adolescents and young adults in Turkey. Hum Vaccines Immunother. 2017;13(5):1182-9.

32. Yetkin G, Ay S, Yetkin Ö, Taştekin N, Güçlüer N. The effect of smoking on the carriage of potential pathogens in nasopharynx. Erciyes Tip Dergisi. 2010;32(1):009-14.

33. Alborzi A, Oskoee S, Pourabbas B, Alborzi S, Astaneh B, Gooya MM, Kaviani MJ. Meningococcal carrier rate before and after hajj pilgrimage: effect of single dose ciprofloxacin on carriage. East Mediterr Health J. 2008;14(2):277-82.

34. Ataee RA, Mehrabi-Tavana A, Hosseini SMJ, Kaviani F. Carriage rates of neisseria meningitidis serogroups: determination among freshmen conscripts before vaccination. Iran J Microbiol. 2016:8(3):203-9.

35. Eslami-Nejad Z, Esmaili M, Saiid-Adeli N, Iranmanesh Z, Honarvar S, Phanii M. Neisseria meningitidis carrier rate among military recruits in Kerman, South-East of Iran. Arch Iran Med. 2005;8(4):304-10.

36. Metanat M, Sharifi-Mood B, Sanei-Moghaddam S, Sepehri Rad N. Pharyngeal carriage rate of Neisseria meningitidis before and after the Hajj pilgrimage, in Zahedan (Southeastern Iran), 2012. Turk J Med Sci. 2015:45(6):1317-20.

37. Sadeghi M, Ahmadrajabi R, Dehesh T, Saffari F. Prevalence of meningococcal carriage among male university students living in dormitories in Kerman, southeast of Iran. Pathog Glob Health. 2018;112(6):329-33.

38. Valipour M, Piroozmand A, Khorshidi A, Akbari $\mathrm{H}$, Mirzaee $\mathrm{H}$. Identification of serological groups A, B, C, W135, Y, X Neisseria meningitidis carriers by multiplex PCR in the nasopharynx of students in Kashan during 2011-2012. Feyz J Kashan Univ Med Sci. 2013;17(2):181-7.

39. Husain EH, Dashti AA, Electricwala QY, Abdulsamad AM, Al-Sayegh S. Absence of neisseria meningitidis from throat swabs of Kuwaiti pilgrims after returning from the Hajj. Med Princ Pract. 2010;19(4):321-3. 
40. Al-Azeri A, Altuhami H, Al-Rabeah A, Alhamdan N, Aljefri M, et al. Meningococcal carriage among Hajjis in Makkah, $1421 \mathrm{H}$. Saudi Epidemiol Bull. 2002;9(1):3-4

41. Ashgar SS, El-Said HM, Johargy A, Momenah A, Asghar A, Sorour A, Alherabi A, Mashat BH, Aalam A. Prevalence of nasal carriage of Neisseria meningitidis among Umrah visitors and pilgrims during Umrah and Hajj season. Glo Adv Res J Microbiol. 2013;2:141-9.

42. Balkhy HH, Memish ZA, Almuneef MA, Osoba AO. Neisseria meningitidis W-135 carriage during the Hajj season 2003. Scand J Infect Dis. 2004;36(4):264-8.

43. Balkhy $\mathrm{HH}$, Memish ZA, Osoba AO. Meningococcal carriage among local inhabitants during the pilgrimage 2000-2001. Int J Antimicrob Agents. 2003;21(2):107-11.

44. Memish ZA, Al-Tawfiq JA, Almasri M, Azhar El, Yasir M, Al-Saeed MS, Ben Helaby H, Borrow R, Turkistani A, Assiri A. Neisseria meningitidis nasopharyngeal carriage during the Hajj: a cohort study evaluating the need for ciprofloxacin prophylaxis. Vaccine. 2017;35(18):2473-8.

45. Alasmari A, Houghton J, Greenwood B, Heymann D, Edwards P, Larson $H$, Assiri A, Ben-Rached F, Pain A, Behrens R, et al. Meningococcal carriage among Hajj pilgrims, risk factors for carriage and records of vaccination: a study of pilgrims to Mecca. Trop Med Int Health. 2021;26:453-61.

46. Celal Başustaoğlu A, Bedir O, Yilmaz S, Kiliç A, Gümral R, Mert G, Beşirbellioğlu B. Nasopharyngeal carriage rate and serogroups of Neisseria meningitidis in Turkish recruits upon entry to the military. TAF Prev Med Bull. 2011;10(4):447-50

47. Ceyhan M, Celik M, Demir ET, Gurbuz V, Aycan AE, Unal S. Acquisition of meningococcal serogroup W-135 carriage in Turkish hajj pilgrims who had received the quadrivalent meningococcal polysaccharide vaccine. Clin Vaccine Immunol. 2013;20(1):66-8.

48. Tezer H, Gulhan B, Simge Gisi A, Nar Otgun S, Kanik-Yuksek S, OzkayaParlakay A, Kilic S, Unal Sahin N, Simsek AC, Kara A. The impact of meningococcal conjugate vaccine (MenACWY-TT) on meningococcal carriage in Hajj Pilgrims returning to Turkey. Hum Vaccines Immunother 2020;16(6):1268-71.

49. Saeed N, Al Ansari H, Al Khawaja S, Jawad JS, Nasser K, Al Yousef E. Trend of bacterial meningitis in Bahrain from 1990 to 2013 and effect of introduction of new vaccines. East Mediterr Health J. 2016;22(3):175-82.

50. Tavana AM, Ataee RA. Meningococcal meningitis control in Iran: five year comparative study 2000-2004. J Med Sci. 2009;9(1):51-4

51. Husain EH, Barakat M, Al-Saleh M. Trends and variations in the epidemiology of meningococcal disease in Kuwait 1987-2013. J Infect Public Health. 2015;8(5):441-7.

52. Elsaid MF, Alsoub H, Bessisso MS, Janahi M, Elshafie S, Amina A. Clinical presentation of acute bacterial meningitis in Qatar. Neurosciences. 2002;7(4):266-71

53. Al-Mazrou YY, Al-Jeffri MH, Al-Haggar SH, Musa EK, Mohamed OM, Abdalla MN. Haemophilus type B meningitis in Saudi children under 5 year old. J Trop Pediatr. 2004;50(3):131-6.

54. Lingappa JR, Al-Rabeah AM, Hajjeh R, Mustafa T, Fatani A, Al-Bassam T, Badukhan A, Turkistani A, Al-Hamdan N, Al-Jeffri M, et al. Serogroup W-135 meningococcal disease during the Hajj, 2000. Emerg Infect Dis. 2003:9(6):665-71.

55. Memish Z, Al Hakeem R, Al Neel O, Danis K, Jasir A, Eibach D. Laboratory-confirmed invasive meningococcal disease: effect of the Hajj vaccination policy, Saudi Arabia, 1995 to 2011. Eurosurveillance. 2013;18(37):20581.

56. Al-Tawfiq JA, AbuKhamsin A. Burden and etiology of communityacquired bacterial meningitis in a hospital in Eastern Saudi Arabia: 1993-2005. Med Sci Monit. 2009;15(2):PI10-4.

57. Ceyhan M, Gürler NG, Ozsurekci Y, Keser M, Aycan AE, Gurbuz V, Salman N, Camcioglu Y, Dinleyici EC, Ozkan S, et al. Meningitis caused by neisseria meningitidis, hemophilus influenzae type $b$ and streptococcus pneumoniae during 2005-2012 in Turkey: a multicenter prospective surveillance study. Hum Vaccines Immunother. 2014;10(9):2706-12.

58. Ceyhan M, Ozsurekci Y, Gurler N, Karadag Oncel E, Camcioglu Y, Salman N, Celik M, Emiroglu MK, Akin F, Tezer H, et al. Bacterial agents causing meningitis during 2013-2014 in Turkey: a multi-center hospitalbased prospective surveillance study. Hum Vaccines Immunother 2016;12(11):2940-5
59. Ceyhan M, Ozsurekci Y, Tanir Basaranoglu S, Gurler N, Sali E, Keser Emiroglu M, Oz FN, Belet N, Duman M, Ulusoy E, et al. Multicenter hospital-based prospective surveillance study of bacterial agents causing meningitis and seroprevalence of different serogroups of Neisseria meningitidis, Haemophilus influenzae Type b, and Streptococcus pneumoniae during 2015 to 2018 in Turkey. Sphere. 2020;5(2):e00060-20.

60. Al Khorasani A, Banajeh S. Bacterial profile and clinical outcome of childhood meningitis in rural Yemen: a 2-year hospital-based study. J Infect. 2006:53(4):228-34.

61. Nakhla I, Frenck RW Jr, Teleb NA, El Oun S, Sultan Y, Mansour H, Mahoney F. The changing epidemiology of meningococcal meningitis after introduction of bivalent A/C polysaccharide vaccine into schoolbased vaccination programs in Egypt. Vaccine. 2005;23(25):3288-93.

62. Mobarak El. Trend, features and outcome of meningitis in the Communicable Diseases hospital, Alexandria, Egypt, 1997-2006. J Egypt Public Health Assoc. 2012;87(1-2):16-23.

63. Loutfi A, El Hioui M, Jayche S, Mohammed L, Asmaa A, Lhou A, Dahou B, Omar Touhami Ahami A. Epidemiological, cytochemical and bacteriological profile of meningitis among adults and children in north west of Morocco. Pak J Biol Sci. 2020;23(7):891-7.

64. Brik A, Terrade A, Hong E, Deghmane A, Taha MK, Bouafsoun A, Khmiri M, Boussetta K, Boukhir S, Jaballah NB, et al. Phenotypic and genotypic characterization of meningococcal isolates in Tunis, Tunisia: high diversity and impact on vaccination strategies. Int J Infect Dis. 2020;91:73-8.

65. Ministry of Health, Saudi Arabia, ANNUAL STATISTICAL BOOK 2017. Saudi Arabia; 2017.

66. Alert Global World Health Organization. Emergence of W135 Meningococcal disease: report of a WHO Consultation, Geneva 17-18 September 2001. Geneva: World Health Organization; 2002.

67. Attarpour-Yazdi MM, Ghamarian A, Mousaviehzadeh M, Davoudi N. Identification of the serotypes of bacterial meningitis agents; implication for vaccine usage. Iran J Microbiol. 2014;6(4):211-8.

68. Pormohammad A, Lashkarbolouki S, Azimi T, Gholizadeh P, Bostanghadiri N, Safari H, Armin S, Mohtavinejad N, Fallah F. Clinical characteristics and molecular epidemiology of children with meningitis in Tehran, Iran: a prospective study. New Microbes New Infect. 2019;32:100594.

69. Al Maslamani E, Al Soub H, Al Maslamani M, Abu Khatab M. Some of the meningococcal meningitis in Qatar: epidemiology, clinical and laboratory features. Qatar Med J. 2010;19(2):17-21.

70. Al-Mazrou YY, Al-Jeffri MH, Abdalla MN, Elgizouli SA, Mishskas AA. Changes in epidemiological pattern of meningococcal disease in Saudi Arabia: does it constitute a new challenge for prevention and control? Saudi Med J. 2004;25(10):1410-3.

71. Karima TM, Bukhari SZ, Fatani MI, Yasin KA, Al-Afif KA, Hafiz FH. Clinical and microbiological spectrum of meningococcal disease in adults during Hajj 2000: an implication of quadrivalent vaccination policy. JPMA J Pak Med Assoc. 2003;53(1):3-7.

72. Nour M, Alaidarous A. Clinical usefulness and accuracy of polymerase chain reaction in the detection of bacterial meningitis agents in pediatric cerebrospinal fluid. Curr Res Transl Med. 2018;66(1):15-8.

73. Ceyhan M, Yildirim I, Balmer P, Borrow R, Dikici B, Turgut M, Kurt N, Aydogan A, Ecevit C, Anlar Y, et al. A prospective study of etiology of childhood acute bacterial meningitis, Turkey. Emerg Infect Dis. 2008;14(7):1089-96.

74. Özdemir H, Tapisiz A, Çiftçi E, Ince E, Doğru U. Acute bacterial meningitis in children. Cocuk Enfeksiyon Dergisi. 2010;4(1):9-14.

75. Toprak D, Soysal A, Torunołlu MA, Turgut M, Türkołlu S, Pimenta FC, Da Gloria CM, Wang X, Mayer L, Altinkanat G, et al. Pcr-based national bacterial meningitis surveillance in Turkey: years 2006 to 2009. Pediatr Infect Dis J. 2014:33(10):1087-9.

76. Bor M, Cokugras H. Factors associated with early complications in inpatients who were treated in our clinic between 1992 and 2011 with a diagnosis of acute bacterial meningitis. Turk Pediatri Ars. 2020:55(2):149-56.

77. Ceyhan M, Ozsurekci Y, Lucidarme J, Borrow R, Meningitis Surveillance G. Characterization of invasive Neisseria meningitidis isolates recovered from children in Turkey during a period of increased serogroup $B$ disease, 2013-2017. Vaccine. 2020;38(19):3545-52

78. Afifi S, Wasfy MO, Azab MA, Youssef FG, Pimentel G, Graham TW, Mansour H, Elsayed N, Earhart K, Hajjeh R, et al. Laboratory-based 
surveillance of patients with bacterial meningitis in Egypt (1998-2004). Eur J Clin Microbiol Infect Dis. 2007;26(5):331-40.

79. Youssef FG, El-Sakka H, Azab A, Eloun S, Chapman GD, Ismail T, Mansour $H$, Hallaj Z, Mahoney F. Etiology, antimicrobial susceptibility profiles, and mortality associated with bacterial meningitis among children in Egypt. Ann Epidemiol. 2004;14(1):44-8.

80. El Fakiri K, Bourrous M, Diffo C, Rada N, Draiss G, Bouskraoui M. The meningitis in infants and children at the university hospital of Marrakech: experience of a Moroccan pediatric unit. J Pediatr Pueric. 2016;29(5):237-43.

81. El Mdaghri N, Jilali N, Belabbes H, Jouhadi Z, Lahssoune M, Zaid S. Epidemiological profile of invasive bacterial diseases in children in Casablanca, Morocco: antimicrobial susceptibilities and serotype distribution. East Mediterr Health J. 2012;18(11):1097-101.

82. Razki A, Hong E, Zerouali K, Belabbes H, Aitmouss K, Terrade A, Zaki B, Deghmane AE, Elmdaghri N, Taha MK. Molecular characterization of invasive isolates of neisseria meningitidis in casablanca, Morocco. J Clin Microbiol. 2018;56(7):e00445-18.

83. Zerouali K, Elmdaghri N, Boudouma M, Benbachir M. Serogroups, serotypes, serosubtypes and antimicrobial susceptibility of Neisseria meningitidis isolates in Casablanca, Morocco. Eur J Clin Microbiol Infect Dis. 2002;21(6):483-5.

84. Ait Mouss K, Razki A, Hong E, Zaki B, Maaloum F, Nzoyikorera N, Belabbes $\mathrm{H}$, Elmdaghri $\mathrm{N}$, Zerouali K. Epidemiological profile of Neisseria meningitidis in Casablanca, Morocco: 2010-2019. Access Microbiol. 2020;2(9):acmio00157.

85. Ikken Y, Charof R, Benaouda A, Hilali F, Akkaoui S, Elouennass M, Sekhsokh Y. Epidemiology and antibiotic resistance profile of bacterial meningitis in Morocco from 2015 to 2018. Acta Microbiol Immunol Hung. 2020;67(4):243-51.

86. Bettaieb J, Bellali H, Alaya NB, Mrabet A, Chahed MK. Evaluation of the surveillance of invasive meningococcal disease in Tunis: capturerecapture method. Sante publique (Vandoeuvre-les-Nancy, France). 2013;25(5):609-15.

87. Mezghani Maalej S, Kassis M, Mahjoubi Rhimi F, Damak J, Hammami A. Bacteriology of community acquired meningitis in Sfax, Tunisia (1993-2001). Medecine et maladies infectieuses. 2006;36(2):105-10.

88. Saguer A, Smaoui H, Taha MK, Kechrid A. Characterization of invasive Neisseria meningitidis strains isolated at the Children's Hospital of Tunis, Tunisia. East Mediterr Health J. 2016;22(5):343-9.

89. Smaoui H, Saguer A, Bouziri A, Fourati S, Chahed MK, Ben Jaballah N, Ben Bousnina S, Barsaoui S, Sammoud A, Ben Becheur S, et al. Neisseria meningitidis invasive infections in children in Tunis: about 79 cases. Arch Inst Pasteur Tunis. 2011;88(1-4):35-41.

90. Haddad-Boubaker S, Lakhal M, Fathallah C, Mhimdi S, Bouafsoun A, Kechrid A, Smaoui H. Epidemiological study of bacterial meningitis in Tunisian children, beyond neonatal age, using molecular methods: 2014-2017. Afr Health Sci. 2020;20(3):1124-32.

91. Mamishi S, Mostashfi Habibabadi S, Elahi B. Clinical and laboratory manifestations of meningococcemia in children. Iran J Public Health. 2006:35(4):49-53.

92. Berangi Z, Karami M, Mohammadi Y, Nazarzadeh M, Zahraei SM, Javidrad $\mathrm{H}$, Heidari S. Epidemiological profile of meningitis in Iran before pentavalent vaccine introduction. BMC Pediatr. 2019;19(1):370.

93. Husain EH, Al-Shawaf F, Bahbahani E, El-Nabi MH, Al-Fotooh KA, Shafiq $\mathrm{MH}$, Al-Ateegi N, Talib MAA. Epidemiology of childhood meningitis in Kuwait. Med Sci Monit. 2007;13(5):CR220-3.

94. Sadeq H, Husain EH, Alkoot A, Atyani S, Al-fraij A, Al-Daithan A, AlSaleem $\mathrm{T}$, Taher A, Alenezi M. Childhood meningitis in Kuwait in the era of post pneumococcal conjugate vaccination: a multicenter study. J Infect Public Health. 2017;10(6):766-9.

95. Rabbani MA, Khan AA, Ali SS, Ahmad B, Baig SM, Khan MA, Wasay M. Spectrum of complications and mortality of bacterial meningitis: an experience from a developing country. J Pak Med Assoc. 2003;53(12):580-3.

96. Rizvi SFS, Arif U, Khan MUR. Frequency of etiological agents and the clinical outcome of acute bacterial meningitis. Pak J Med Health Sci. 2016;10(4):1264-7.

97. Akyildiz B, Uzel N, Çitak A, Soysal D, Karaböcüoğlu M, Üçsel R. The factors affecting mortality in meningococcal disease. Cocuk Sagligi ve Hastaliklari Dergisi. 2008;51(1):26-30.
98. Gürgey A, Aytac S, Kanra G, Secmeer G, Ceyhan M, Altay C. Outcome in children with purpura fulminans: report on 16 patients. Am J Hematol. 2005;80(1):20-5.

99. Kara Uzun A, Yöney A, Kunak B, Kanik Yüksek S, Tezer H. Evaluation of children with acute bacterial meningitis treated in two separate time periods in Turkey. Turk J Pediatr Dis. 2018;12(3):193-9.

100. Kepenekli E, Tuygun N, Tanir G. Cocuklarda Invazif Meningokokkal Hastalik: 7 Hastada Klinik Özellikler ve Tedavi Yaklasiminin Degerlendirilmesi/invasive meningococcal disease in children; assessment of clinical features and treatment options in 7 patients. Cocuk Enfeksiyon Dergisi. 2008;2(4):152.

101. Kulcu NU, Say A, Guven F, Degirmenci S, Ozkan A, Masatli R. Evaluation of children with invasive meningococcal disease hospitalized between 2003-2007. J Pediatr Infect. 2008:2(1):7-11.

102. Abdulrab A, Algobaty F, Salem AK, Mohammed YAK. Acute bacterial meningitis in adults: a hospital based study in Yemen. Jpn J Infect Dis. 2010;63(2):128-31.

103. Teleb N, Pilishvili T, Van Beneden C, Ghoneim A, Amjad K, Mostafa A, Estighamati AR, Smeo MN, Barkia A, EIKhatib M. Bacterial meningitis surveillance in the Eastern Mediterranean region, 2005-2010: successes and challenges of a regional network. J Pediatr. 2013;163(1):S25-31.

104. Gueddari W, Sabri H, Chabah M. Meningococcal infections associated with febrile purpura among children hospitalized in a moroccan hospital: incidence and associated clinical factors. Pan Afr Med J. 2017;28:123.

105. Alam J, Baig JA, Hussain A, Mahmood SR, Sultana I, Ansari MA. Evaluation of neuron specific enolase (NSE) levels in children with bacterial and viral meningitis. Int J Biol Biotechnol. 2011;8(1):65-70.

106. Mahmoudi S, Zandi H, Pourakbari B, Haghi Ashtiani MT, Mamishi S. Acute bacterial meningitis among children admitted into an Iranian referral children's hospital. Jpn J Infect Dis. 2013;66(6):503-6.

107. Yamazhan T, Arda B, Tasbakan M, Gokengin D, Ulusoy S, Serter D. Analysis of 94 cases with acute purulent meningitis. KLIMIK Dergisi. 2004:17:95-8.

108. Oordt-Speets AM, Bolijn R, van Hoorn RC, Bhavsar A, Kyaw MH. Global etiology of bacterial meningitis: a systematic review and meta-analysis. PLOS ONE. 2018;13(6):e0198772.

109. WHO Technical Taskforce. Defeating meningitis by 2030. https://www. who.int/immunization/research/Defeating_meningitis_2030_TTFJu ly2018_report.pdf?ua=1. Accessed July 2020.

110. Shaker R, Fayad D, Dbaibo G. Challenges and opportunities for meningococcal vaccination in the developing world. Hum Vaccines Immunother. 2018;14(5):1084-97.

111. Zhang Y, Wei D, Guo X, Han M, Yuan L, Kyaw MH. Burden of Neisseria meningitidis infections in China: a systematic review and meta-analysis. J Glob Health. 2016;6(2):020409.

112. Parikh SR, Campbell H, Bettinger JA, Harrison LH, Marshall HS, MartinonTorres F, Safadi MA, Shao Z, Zhu B, von Gottberg A, et al. The everchanging epidemiology of meningococcal disease worldwide and the potential for prevention through vaccination. J Infect. 2020;81:483-98.

113. Aye AMM, Bai X, Borrow R, Bory S, Carlos J, Caugant DA, Chiou CS, Dai VTT, Dinleyici EC, Ghimire P, et al. Meningococcal disease surveillance in the Asia-Pacific region (2020): the Global Meningococcal Initiative. J Infect. 2020;81:698-711.

114. Vespa Presa J, Abalos MG, SinideAlmeida R, Cane A. Epidemiological burden of meningococcal disease in Latin America: a systematic literature review. Int J Infect Dis. 2019;85:37-48.

115. Peterson ME, Li Y, Bita A, Moureau A, Nair H, Kyaw MH, Meningococcal Surveillance G, Abad R, Bailey F, Garcia IF, et al. Meningococcal serogroups and surveillance: a systematic review and survey. J Glob Health. 2019:9(1):010409.

116. Meningococcal disease: situation in the African Meningitis Belt. WHO. https://www.who.int/csr/don/2012 05 24/en/\#: :text=The\%2014\% 20countries\%20in\%20the,\%2C\%20Nigeria\%2C\%20Sudan\%20and\% 20Togo.

117. Meningococcal A conjugate vaccine: updated guidance, February 2015. https://www.who.int/wer/2015/wer9008.pdf?ua=1. Accessed May 2020.

118. Reese HE, Ronveaux O, Mwenda JM, Bita A, Cohen AL, Novak RT, Fox LM, Soeters HM. Invasive meningococcal disease in Africa's meningitis belt: more than just meningitis? J Infect Dis. 2019;220(Supplement_4 ):S263-5. 
119. Vuocolo S, Balmer P, Gruber WC, Jansen KU, Anderson AS, Perez JL, York LJ. Vaccination strategies for the prevention of meningococcal disease. Hum Vaccines Immunother. 2018;14(5):1203-15.

120. Health Requirements and Recommendations for Travellers to Saudi Arabia for Hajj and Umrah. WHO. https://www.who.int/ith/ITH-Haj-2019. pdf?ua=1. Accessed May 2020.

121. Invasive Bacterial Vaccine Preventable Diseases Laboratory Network WHO. https://www.who.int/immunization/monitoring_surveillance/ burden/laboratory/IBVPD/en/. Accessed May 2020.

122. Tezer H, Gülhan B, Simge Gişi A, Nar Ötgün S, Kanık-Yüksek S, ÖzkayaParlakay A, Kılıç S, Ünal Şahin N, Şimşek A, Kara A. The impact of meningococcal conjugate vaccine (MenACWY-TT) on meningococcal carriage in Hajj Pilgrims returning to Turkey. Hum Vaccines Immunother. 2020;16(6):1268-71.
123. Tracy A, Waterfield T. How to use clinical signs of meningitis. Arch Dis Child Educ Pract Ed. 2020;105(1):46-9.

124. Al-Mazrou YY, Musa EK, Abdalla MN, Al-Jeffri MH, Al-Hajjar SH, Mohamed OM. Disease burden and case management of bacterial meningitis among children under 5 years of age in Saudi Arabia. Neurosciences. 2004;9(1):38-45.

\section{Publisher's Note}

Springer Nature remains neutral with regard to jurisdictional claims in published maps and institutional affiliations.
Ready to submit your research? Choose BMC and benefit from:

- fast, convenient online submission

- thorough peer review by experienced researchers in your field

- rapid publication on acceptance

- support for research data, including large and complex data types

- gold Open Access which fosters wider collaboration and increased citations

- maximum visibility for your research: over $100 \mathrm{M}$ website views per year

At BMC, research is always in progress.

Learn more biomedcentral.com/submissions 